\title{
Abundance of bottlenose dolphins, Tursiops truncatus (Cetacea: Delphinidae), inhabiting the Patos Lagoon estuary, southern Brazil: Implications for conservation
}

\author{
Pedro F. Fruet ${ }^{1,3}$; Eduardo R. Secchi ${ }^{1}$; Juliana C. Di Tullio ${ }^{1} \&$ Paul G. Kinas $^{2}$ \\ ${ }^{1}$ Museu Oceanográfico "Prof. Eliézer de Carvalho Rios", Universidade Federal do Rio Grande. Caixa Postal 379, \\ 96200-580, Rio Grande, RS, Brasil. \\ ${ }^{2}$ Laboratório de Estatística Ambiental, Instituto de Matemática e Física, Universidade Federal do Rio Grande. \\ Caixa Postal 474, 96200-970 Rio Grande, RS, Brasil. \\ ${ }_{3}^{3}$ Corresponding author. E-mail: pfruet@yahoo.com.br
}

\begin{abstract}
A new mark-recapture abundance estimate and a photographic census were carried out to investigate the possible decline in the abundance of the bottlenose dolphins, Tursiops truncatus (Montagu, 1821), in the Patos Lagoon estuary due to the high levels of bycatch mortality which occurred between 2002 and 2006 in oceanic coastal areas close to the estuary. Fourteen systematic boat surveys were conducted between August and early December 2005 to photo-identify the bottlenose dolphins. The estimated number of animals, with long-lasting marks, in the population obtained from Chapman's and $\mathrm{M}_{\mathrm{th}}$ models were $51(95 \% \mathrm{Cl}=49-53)$ and $52(95 \% \mathrm{Cl}=51-60)$, respectively. Taking into account the proportion of dolphins with long-lasting marks in the population, the total estimated population size ranged between $84(95 \% \mathrm{Cl}=76-93)$ and $86(95 \% \mathrm{Cl}=78-95)$ individuals, respectively, which was very similar to the 84 individuals revealed by the population census. Our results did not differ from the abundance estimate carried out in 1998 , prior to the high fishing-related mortality event, suggesting that the population is stable. Plausible argument to explain the stability of the population is that some carcasses found on the oceanic coastal beaches near Patos Lagoon estuary come from animals that do not belong to the estuary community. Future studies should investigate fine-scale habitat partition between estuarine and adjacent coastal dolphins. If the existence of different communities living in close proximity (estuarine and coastal areas near to the estuary) is confirmed, a new abundance estimate is needed to access the conservation status of bottlenose dolphins in this region.
\end{abstract}

KEY WORDS. Cetaceans; mark-recapture; photoidentification.

Threats to wild life around the globe have increased as a result of the growth in human population activities and development. In marine ecosystems, several kinds of fishing operations are known to catch untargeted species and this is probably the major threat to the long-term persistence of some coastal cetaceans (READ et al. 2006). To know the current size of a population it is necessary to make quantitative predictions about how populations will change, to understand both selective and demographic pressures and to make recommendations for species management (Heppel et al. 2000).

Distributed in tropical and temperate waters around the world the bottlenose dolphin, Tursiops truncatus (Montagu, 1821), inhabits a variety of marine environments such as ocean pelagic waters, coastal bays and estuaries (LEATHERWOOd \& REeves 1983). In southern Brazil, the species is continuously distributed along the coastal waters of Santa Catarina and Rio Grande do Sul states, apparently forming small local communities in four distinct geographical areas: the Imaruí-Santo Antonio La- goon system $\left(28^{\circ} 30^{\prime} \mathrm{S}, 48^{\circ} 55^{\prime} \mathrm{W}\right)$; the Mampituba $\left(29^{\circ} 19^{\prime} \mathrm{S}\right.$, $\left.49^{\circ} 42\right)$ and Tramandaí $\left(29^{\circ} 58^{\prime} \mathrm{S}, 50^{\circ} 06^{\prime} \mathrm{W}\right)$ river mouths; and in the Patos Lagoon estuary $\left(32^{\circ} 07^{\prime} \mathrm{S}, 52^{\circ} 05^{\prime} \mathrm{W}\right.$ ) (CASTELLo \& Pinedo 1977, Simões-Lopes \& Fabian 1999) (Fig. 1). Previous research conducted in these areas include behavior, distribution, acustic, diet, habitat use patterns, abundance and fishery interactions studies (Simões-Lopes \& Fabian 1999, Dalla Rosa 1999, Mattos et al. 2007, Azevedo et al. 2007, Di Tullio 2009, Fruet et al. 2010). The degree of isolation and movements of individuals among these communities remain poorly understood. However, it is known that they constitute distinctive small geographical communities, have strong and long-term site fidelity and apparently few interchange of individuals (DALLA Rosa 1999, Simões-Lopes \& Fabian, 1999). Past photo-identification data (Castello \& Pinedo 1977, Dalla Rosa 1999, Simões-Lopes \& FABIAN 1999) suggest that the largest community resides in the Patos Lagoon estuary and adjacent coastal waters, where different kinds of human activities (e.g. fishery, boat traffic and 
pollution) may harm bottlenose dolphins. These dolphins tend to concentrate near the estuary mouth, but the estuary and adjacent areas are relevant for bottlenose dolphin activities, including resting, feeding, reproduction and social interactions (e.g. Matтos et al. 2007). The use of the photo-identification technique to recognize individual dolphins in the Patos Lagoon estuary began in the mid 1970s (CASTello \& Pinedo 1977), but population abundance was estimated only two decades later. Dalla Rosa (1999) applied photo-identification data to mark-recapture models for a closed population and estimated that 83 dolphins (95\% CI: 78-88) inhabited the waters of Patos Lagoon estuary in 1998.

Until recently, coastal fisheries were thought not to harm bottlenose dolphins. Pinedo (1986), after seven years of beach surveys along Rio Grande do Sul state coast, suggested that incidental catches in fishing gear were not a major cause of mortality of bottlenose dolphins. However, a recent investigation, based on a time series of stranding data revealed a significant trend of increasing mortality of bottlenose dolphins over the past 14 years in coastal areas close to the estuary (FRUET et al. 2010). High levels of mortality, representing 5\% to $17 \%$ of the mean population size, occurred between 2002 and 2006. During this period the bycatch was responsible for, at least $42 \%$ of the overall mortality. Potential Biological Removal (PBR) analysis (sensu $\mathrm{W}_{\mathrm{ADE}}$ 1998) suggests that current levels of bycatch in artisanal fisheries are unsustainable and this population could be declining (Fruet et al. 2010). The aim of this work was to perform a new mark-recapture abundance estimate for the bottlenose dolphins inhabiting the Patos Lagoon estuary in order to investigate whether or not this population is declining.

\section{MATERIAL AND METHODS}

\section{Study area}

The Patos Lagoon estuary, located at Rio Grande do Sul state, southern Brazil, is the world's largest choked coastal lagoon (KJerfve 1986). It is connected to the Atlantic Ocean through a $0.5-3 \mathrm{~km}$ wide strait channel in its southern portion. Although the estuarine ecosystem comprises only 5\% of the total area of the Patos Lagoon this environment holds many habitats including salt marshes, seagrass and shallow estuarine bays, which provide critical habitats for the establishment and development of various fish and crustacean species exploited by both artisanal and industrial fisheries in the region (COSTA et al. 1997). The artisanal fishery, which involves approximately 4,000 traditional fishermen, occurs throughout the year in the estuary and adjacent coastal areas (Reis \& Rodrigues 2003). The region has intense human activity and a high risk of environmental accidents caused by the continuous traffic of fishing and merchant vessels, petrochemical and fertilizer industries established on the estuarine margins and frequent dredging activities (TAgLiani et al. 2003).

\section{Data collection}

Between August and December 2005, we carried out 14 bottlenose dolphin photo-identification surveys in the Patos Lagoon estuary. Surveys were conducted along a predefined route, comprising an area of approximately $40 \mathrm{~km}^{2}$ (similar to the route adopted by DaLla Rosa 1999) (Fig. 1). All surveys started at the north portion and extended south to the mouth of the estuary. Zig-zag transects were run throughout the study area onboard a $5.3 \mathrm{~m}$ aluminum vessel equipped with a $60 \mathrm{hp}$ outboard engine at speeds around $18-22 \mathrm{~km} / \mathrm{h}$. In all surveys the same photographer and boat pilot were present. A third person was responsible for recording data and helping the photographer find the dolphins. Usually the surveys extended from early mornings to late afternoons but were occasionally halted if weather conditions deteriorated due to rain, fog and/or strong winds.

A 'group' was defined as aggregations of dolphins within $100 \mathrm{~m}$ of one another engaged in similar activities and, if moving, heading in the same direction (Wells et al. 1987). Whenever dolphins were sighted, the survey route was abandoned and the boat was slowed and the individual(s) approached carefully. The geographical position of the initial sighting location was recorded using a hand held Geographical Position System (GPS) Garmin E-TREX Legend. The boat was maintained parallel to the individuals to initiate the photo-identification data collection following the protocol described by WÜRSIG \& JefFerson (1990). Photographs were taken using a Nikon D70 digital camera equipped with a $300 \mathrm{~mm}$ (f 2.1) lens. Photographs were taken randomly from dorsal fins of all animals in the group, regardless whether there were obvious long-lasting marks or not. As many photographs as possible were taken aiming to increase the likelihood of obtaining at least one good quality picture of each group member. Back-lit shots (which give little detailed of skin markings) were avoided (WILson et al. 1999). After ensuring that a sufficient number of good quality pictures had been taken, the group was left and the survey was continued until the route was completed. After covering the entire area, we kept searching for dolphins near the estuary mouth where they tend to concentrate (see Fig. 1). Estimations of group size were repeated several times during a survey and subsequently confirmed with the photographic material following the procedure described by BALLANCE (1990).

\section{Individual identification}

Each photograph was graded according to its quality: excellent, medium and poor. The dorsal fin needed to be clearly visible and large enough to allow the detection of any irregularities on either its leading or trailing edge. To be considered excellent, photographs were required to be well exposed, without water droplets, in sharp focus, with the dorsal fin orientated parallel to, and occupying a large proportion of the frame (Hammond et al. 1990). Photographs not meeting these criteria (medium and poor quality photos) were excluded from the analysis. These data restrictions aimed to reduce the chance of 


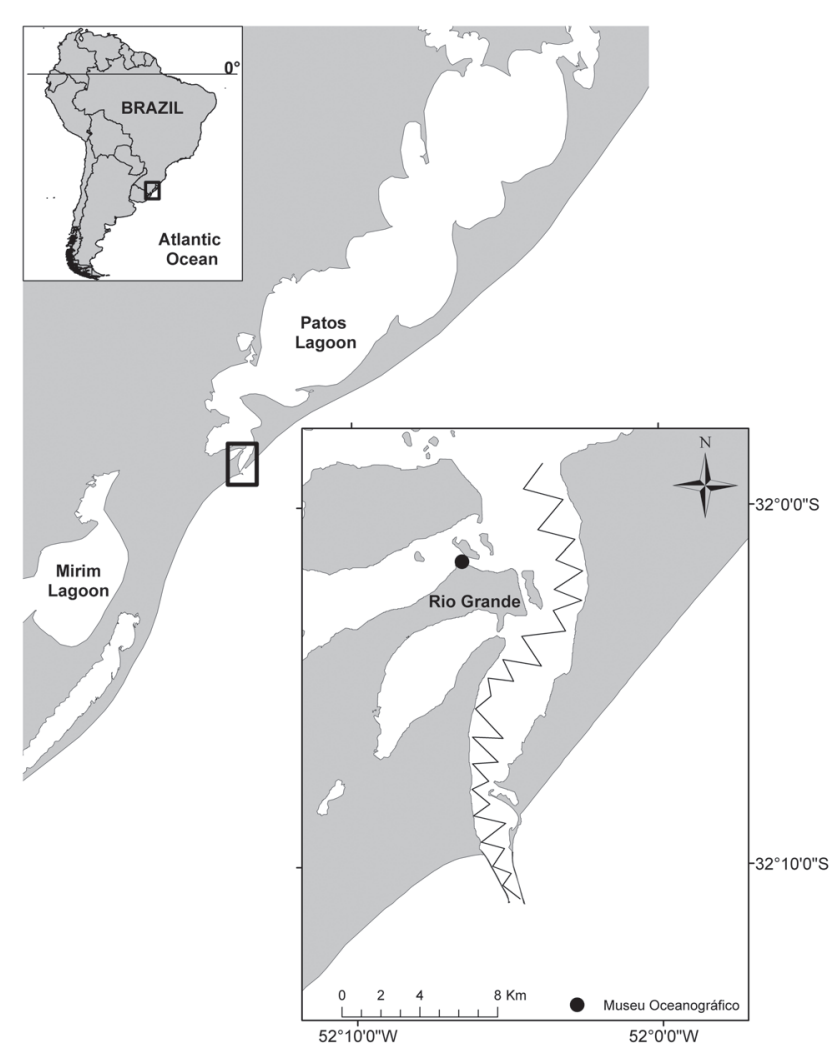

Figure 1. Survey route followed during survey trips conducted in the Patos Lagoon estuary, southern Brazil.

incorrect identifications (false positive/negative) (FridAY et al. 2000). Only long-lasting marks, such as nicks, cuts and deformities were used for individual identification (WÜRSIG \& WÜRSIG 1977). Other mark types such as dorsal fin shape, rakes, epidermal disease and injuries were only used to assist in differentiating individuals without long-lasting marks. After each survey, good quality photographs of dorsal fins possessing longlasting marks were catalogued. Photo-identified individuals from subsequent surveys, which did not match any of the previously catalogued animals, were added to the catalogue. Otherwise, they were considered as a recapture.

\section{Estimating the number of marked animals}

The use of standard mark-recapture models involves some assumptions and their violation can lead to bias estimates (SEBER 1982). Thus, it is important that they are explored and validated, or that appropriate models are selected to "relax" some assumptions that are not met (BEGON 1983). Analysis of markrecapture for closed populations usually assume the following: (1) The population is closed (events of births and deaths, immigration and emigration do not occur during the study period); (2) All individuals in the population have the same probability of capture; (3) Marks are not lost during the sampling period; (4) A marked individual will be correctly recognized upon recapture; and (5) The capture of an animal does not affect its subsequent probability of recapture.

\section{Data selection}

The pronounced bycatch mortality and births in the Patos Lagoon community of bottlenose dolphins are seasonally defined, occurring between November and March (Laboratório de Tartarugas e Mamíferos Marinhos, Universidade Federal do Rio Grande (LTMM/FURG) - unpubl. data). To reduce the chance of violating the closed population assumption, we restricted the data analysis from surveys carried out between August and early December of 2005. On some occasions, we observed the same groups of dolphins using same sites in our study area on consecutive days. Thus, surveys carried out on consecutive days were excluded from the analysis (in this case, the survey with the lowest number of photographs was excluded) to avoid problems associated with "pseudoreplication" (WILson et al. 1999). Pseudoreplication data may introduce negative bias in the estimate because it decreases the likelihood of "capture" of different individuals in the population introducing dependence between observations.

\section{Mark-recapture models}

The estimates of the number of dolphins with long-lasting marks in the population were based on two mark-recapture models for closed populations: Chapman's modification of the Lincoln-Petersen estimator (CH) (CHAPMAN 1951) and the $\mathrm{M}_{\text {th }}$ model (Otis et al. 1978, Снао et al. 1992).

The first model $(\mathrm{CH})$ considers only two sampling periods and assumes the same capture probabilities among individuals. In this case, we considered the first seven surveys as the capture period and the last seven as the recapture period.

For the second model $\left(\mathrm{M}_{\mathrm{th}}\right)$ (CHaO et al. 1992), which assumes heterogeneity and time variation in the capture probabilities, an x-matrix representing the capture history of each marked individual was constructed. This absence/presence matrix was used to run the model in the Capture software (Rexstad \& Burnham 1991).

\section{Total population size estimation $\left(\hat{\mathbb{N}}_{\mathrm{T}}\right)$}

Since not all dolphins possess long-lasting marks in the population, the total population size was obtained by dividing $\hat{\mathrm{N}}$ by the estimated proportion of marked individuals in the population $(\hat{\theta})$, with variance estimated using the delta method (SEBER 1982), as modified by WiLson et al. (1999). Some researchers estimate $\theta$ as the ratio between the number of high quality-photos of individuals presenting long-lasting marks and the total number of dorsal fin photographs taken (e.g. Williams et al. 1993, Currey et al. 2008). However, we believe that the use of this method can produce bias because it is affected by the individual variation in capture probability within the group sampled. In our study area, for example, juvenile/sub-adult dolphins usually got closer to our research vessel than adults and were easier to photograph, whereas older individuals with 
more long-lasting marks (WILSON et al. 1999) stayed farther apart from the vessel. Therefore, it is expected that a smaller number of good-photographs from these animals was taken during surveys, underestimating $\theta$ and overestimating total population size. This was because marked dolphins compose a large proportion of the population, mean group size is small (4) (MAтTos et al. 2007) and the varieties of skin markings made it possible to distinguish the unmarked dolphins in each group.

As recommended by Burnham et al. (1987) the 95\% confidence interval for all estimates was constructed assuming a lognormal approximation.

\section{Population census}

Parallel to abundance estimates, a photographic census was conducted by recording the total number of individuals recognized during the fieldwork period. The individual identification was made based on all kinds of dorsal fin marks, like dorsal fin shapes, rakes, epidermal diseases and injuries, which allowed us to recognize individuals throughout the sampling period. The photographic census was performed independently for the right and left side of the dorsal fin and included dolphins in all life stages. As young bottlenose dolphins stay in close association with their mothers in the first three years of life (Wells 2000) and in most cases, do not possess any kind of dorsal fin marks, we assigned as "individual" only unmarked young dolphins sighted in two or more surveys in close association with the presumed mother. We added the total number of identified calves to the total marked population census.

\section{RESULTS}

\section{Photo-identification}

Fourteen photo-identification surveys were made between August and early December in the study area, totaling 104 hours of sampling effort (Tab. I). Bottlenose dolphins were found in all surveys and 135 groups were sighted. The group size ranged between 1 and 23 individuals $($ mode $=3$, mean $=4.3, \mathrm{SD}=3.4$ ). We took 2271 dorsal fin photographs and 1427 (62.8\%) were graded as excellent quality photographs. Fifty dolphins were recognized through conspicuous long-lasting marks on the dorsal fin. The sighting frequency of these individuals during the study period ranged between 1-10 times (mean $=4.5, \mathrm{SD}=2.5$ ).

\section{Estimates of the number of animals with long- lasting marks in the population}

The number of marked dolphins seemed to be stable over the sampling period, with the majority of the individuals (62\%) sighted on 4 or more occasions (Fig. 2). Six dolphins (12\%) were photographed only once in the study area. The rate of newly identified animals decreased as the survey effort increased, as indicated by the "discovery curve", suggesting that almost or all marked individuals in the population were captured during the experiment (Fig. 3). During the sampling period the asymptote (defined as the observation of $95 \%$ of the photo-identified dolphins) was reached in the ninth field survey.

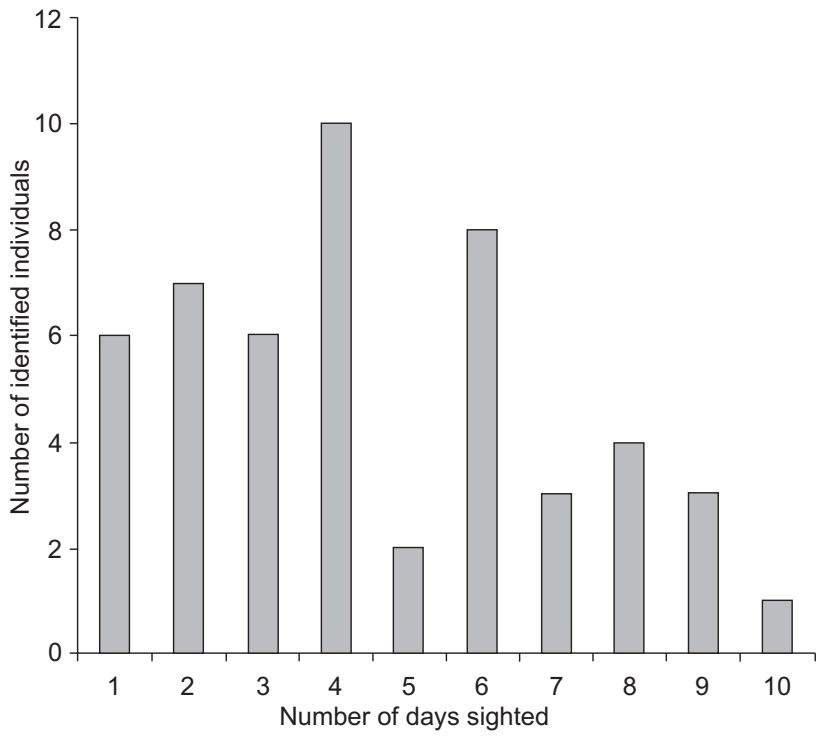

Figure 2. Sighting frequencies of bottlenose dolphins presenting conspicuous long-lasting marks on the dorsal fin.

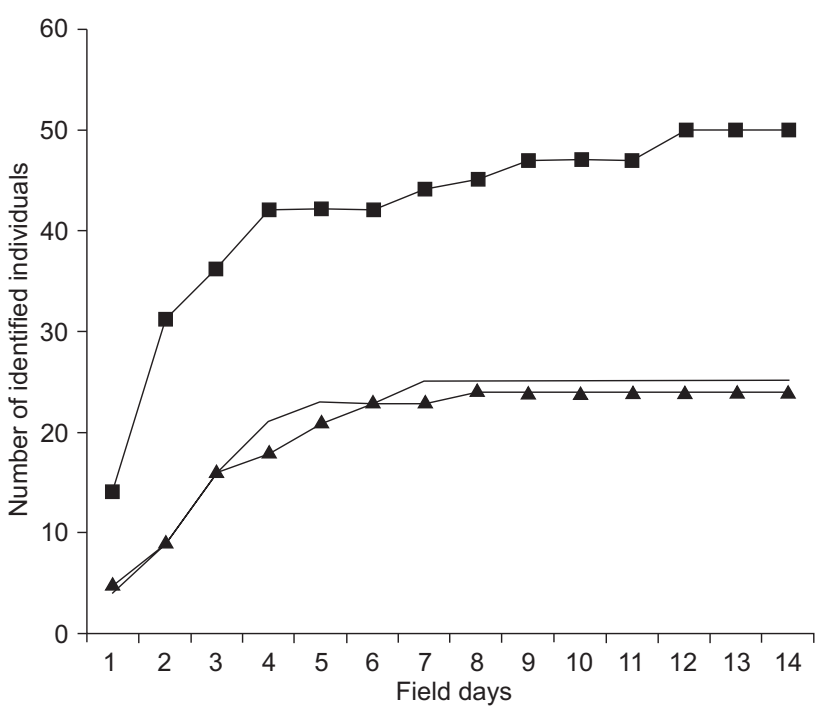

Figure 3. Discovery curves of identified bottlenose dolphins in the Patos Lagoon estuary, Brazil. Line with square markers: dolphins presenting conspicuous long lasting marks on the dorsal fin. Line with triangular markers: dolphins identified by temporary marks in the left side of the dorsal fin, without long-lasting marks. Line free of markers: dolphins identified by temporary marks in the right side of the dorsal fin, without long-lasting marks.

Both $\mathrm{CH}$ and $\mathrm{M}_{\text {th }}$ models estimated similar numbers of dolphins with long-lasting marks in the population $(\hat{\mathrm{N}})$ (Tab. II). According to these models, 51 and 52 dolphins possess conspicuous long-lasting marks in the population, respectively. 
Table I. Field effort (expressed as days and hours), number of groups sampled and total number of dolphins photo-identified for each month during the study period.

\begin{tabular}{lcccccc}
\hline & August & September & October & November & December & Total \\
\hline N Field surveys & 4 & 3 & 3 & 3 & 1 & 14 \\
Time effort (h:min) & $29: 37$ & $20: 15$ & $25: 57$ & $22: 32$ & $05: 39$ & $104: 00$ \\
N groups sampled & 42 & 31 & 28 & 30 & 52 & 135 \\
N identifcations & 57 & 62 & 33 & 52 & 22 \\
\hline
\end{tabular}

Table II. Capture-recapture abundance estimates of bottlenose dolphins, T. truncatus, inhabiting the Patos Lagoon estuary during the 2005 winter/spring season. The number of dolphins with long-lasting marks in the population ( $\hat{N})$, estimated by Chapman's and the Mth models, and the mark rate $(\hat{\theta})$ are also showed. $(\mathrm{Mt}+1)$ the number of animals marked during the experiment, (SE) standard error, (CV) coefficient of variation, $(\mathrm{Cl}) 95 \%$ confidence interval.

\begin{tabular}{lccccccccccc}
\hline & $\mathrm{M} \mathrm{t}+1$ & $\hat{\mathrm{N}}$ & $\mathrm{SE}$ & $\mathrm{CV}$ & $\mathrm{C} . \mathrm{I}$ & $\hat{\theta}$ & $\mathrm{SE}$ & $\mathrm{CV}$ & $\hat{\mathrm{N}}_{\mathrm{T}}$ & $\mathrm{CV}$ & $\mathrm{C} . \mathrm{I}$ \\
\hline Chapman & 50 & 51 & 1.21 & 0.02 & $49-53$ & 0.61 & 0.02 & 0.033 & 84 & 0.036 & $76-93$ \\
Mth & 50 & 52 & 2.13 & 0.04 & $51-60$ & 0.61 & 0.02 & 0.033 & 85 & 0.053 & $78-95$ \\
\hline
\end{tabular}

The proportion of marked animals in the population $(\hat{\theta})$, estimated from 119 groups (376 individuals), was $60.5 \%$ (Tab. II). This value was used to estimate the total population size, which ranged between 84 and 86 individuals. Even assuming the upper limit of the confidence interval provided by $\mathrm{M}_{\mathrm{th}}$, which represents the highest value in the estimate, the population size did not exceed 95 individuals (Tab. II).

\section{Population Census}

We could identify 24 and 25 dolphins for left and right sides, respectively. Nine young dolphins (seven calves born during the 2004/2005 summer and two, more than one yearold, juveniles), without conspicuous marks in their dorsal fins, were identified by their close association with the presumed mother and added to our population census. Considering that 50 dolphins were identified by conspicuous long-lasting marks, our census revealed that at least 84 bottlenose dolphins inhabited the Patos Lagoon estuary during the study period. The discovery curve of individuals was very similar for both sides of the dorsal fin, reaching the asymptotic in the seventh and eighth surveys for right and left sides, respectively (Fig. 3), suggesting that the unmarked population also remained stable during the experiment and that probably all individuals in the study area were sampled.

\section{DISCUSSION}

\section{Abundance estimates}

The assumptions of mark-recapture models used for closed populations appears to be satisfied in this study. The use of excellent quality photographs, the high re-capture rates of marked individuals, the short sampling period and the pattern of the discovery curve strongly suggest that the population remained closed to events of immigration and emigration during the study period (assumption 1). Chances of failure of the closed population assumption could be introduced by the occurrence of births and deaths during our sampling period (four field trips (28.5\%) were performed during a period of pronounced bycatch and of bottlenose dolphins births, within the Patos Lagoon estuary community). However, a $96.2 \%$ re-sighting rate of photo-identified individuals between 2005 and 2006 (only one individual captured in 2005 was not recaptured in 2006) (Laboratório de Tartarugas e Mamíferos Marinhos, Universidade Federal do Rio Grande (LTMM/FURG) - unpubl. data) and the undocumented presence of newborns in the groups sampled up to the last survey trip virtually eliminate this possibility. Photograph quality and short sampling period also reduce the chances of failure of assumptions 3 and 4 (marks are not lost during the experiment and a marked individual will be correctly recognized on recapture, respectively). By using the $\mathrm{M}_{\text {th }}$ model, which takes into account the temporal and individual variations, and the Chapman modification of the Lincoln-Petersen estimator, which tends to reduce the effects caused by individual heterogeneity (CALAmBOKidis et al. 1990), it was possible to "relax" assumption 2 (all individuals have the same capture probability). The use of photographs to capture individual dolphins increases the likelihood of satisfying assumption 5 (the capture of an animal does not affect its subsequent probability of recapture).

The similar results provided by both mark-recapture models and population census indicate that the Patos Lagoon estuary population is small and that our results are very close to the true population size. Since the population census can be considered as a measure of the minimum population size, at least 84 dolphins inhabited the waters of Patos Lagoon estuary during winter and spring. The shape of the discovery curve and sighting frequencies of marked dolphins confirmed that the majority of the individuals sighted are residents of the surveyed area. 
The population size estimated for the Patos Lagoon estuary is within the range of values reported for coastal populations of T. truncatus around the world - e.g. 71 in Doubtful Sound, New Zealand: Currey et al. (2007); 129 individuals in the Moray Firth, Scotland: Wilson et al. (1999); 100 individuals, Sarasota Bay, Florida: Wells \& ScotT (1990) -, and confirms the occupancy patterns as described for other coastal areas which form small resident communities associated with highly productive rivers mouths, estuaries, bays and fjords.

The restricted geographic ranges, disjunct distributions, limited movements and strong dependence of bottlenose dolphins on specific environmental characteristics, make them particularly vulnerable to habitat loss and degradation (REEves et al. 2003). As the population size decreases, the risk of extinction increases due to loss of genetic diversity as a result of inbreeding, along with environmental and demographic stochastic effects (e.g. Fowler \& BAKER 1991). Population viability analysis of well known small coastal cetacean species - e.g. T. truncatus and Cephalorhynchus hectori (P.-J. van Bénéden, 1881) - indicates that populations composed of less than 100 individuals have high probability of extinction even when non-natural mortality rates are relatively low (ThOMPson et al. 2000, SLOOTEN 2007). Due to the high bycatch mortality rates of bottlenose dolphins registered after 2002, there would be an expected decline in the population size from 1998 (the year of the first abundance estimate - see Dalla Rosa 1999) to 2005 (present study). Nevertheless, the two abundance estimates were very similar, suggesting that this decline has not occurred. WILSON et al. (1999) estimated that more than eight years is needed to detect significant trends in the population size of bottlenose dolphins with a declining rate of less than $5 \%$ a year when precise mark-recapture abundance estimates (with CV of up to 0.12 ) are obtained. On average, 10 dolphins were found dead on the beach each year between 2002 and 2005, which represents a minimum annual mortality rate of $11 \%$ of the entire population. Considering that the estimated number of bottlenose dolphin's mortality might be under-estimated (as some dead animals might not have been found) and our abundance estimates have twice the accuracy of those described by WILSON et al. (1999), the rate of change should be high enough to detect population decline.

A plausible argument to explain the stability of the population is that the carcasses found on the oceanic coastal beaches near Patos Lagoon estuary come from another group of dolphins that do not regularly inhabit the estuary and do not belong to the population from which we obtained the abundance estimates. "Coastal" and "estuarine" communities of Indo-Pacific bottlenose dolphins Tursiops aduncus (Ehrenberg, 1832) living in close proximity were recently described in Australia (Möller et al. 2007). The authors could identify five dolphin communities (two estuarine and three coastal) along $130 \mathrm{~km}$ of coast and reported that dolphin communities living in very close geographic proximity $(<16 \mathrm{~km})$ but in two different envi- ronments - open coast and enclosed embayment - exhibited unexpected genetic differentiation. In fact, bottlenose dolphins living in protected coastal environments usually show a high degree of site fidelity to local areas and belong to relatively small communities or populations (Wells et al. 1987), whereas those inhabiting less protected waters such as open coasts tend to display more extensive ranging patterns and gene flow. During surveys conducted to investigate the habitat use of bottlenose dolphins in oceanic coastal areas adjacent to the Patos Lagoon estuary, we recorded some marked dolphins that have never been photographed in the estuary. If these animals were mixed in the stranding samples, as they probably were, this would overestimate the effect of fishing-related mortality to the estuary population. In this way, expanding the photo-identification sampling area towards the coastal zone is critical for better understanding the social structure and habitat partitioning of the bottlenose dolphins in this region. If the existence of different communities living in close proximity (estuarine and coastal areas adjacent to the estuary) is confirmed a new abundance estimate is needed to assess the conservation status of bottlenose dolphins in this region. Furthermore, molecular analysis for these estuarine and open coast communities as well as stranded carcasses would enhance the possibility of evaluating the potential impact of non-natural mortality to these communities.

Even though many questions remain unanswered, there is no doubt that fisheries are affecting bottlenose dolphins in southern Brazil. Conservation and management strategies should address the incidental catch issue by implementing mitigation methods to reduce dolphin mortality. Bycatch was the only human cause of bottlenose dolphin mortality addressed here. Rio Grande city is the main town on the Patos Lagoon estuary margins, with its economy based primarily in port and industrial activities. Contamination of water (Niencheski et al. 2006) and sediments (Mirlean et al. 2003) of the estuary by heavy metals caused by urban effluents, fishprocessing industry and port activities have been described. Infrastructure investments and development projects are occurring in the region and deep social and environmental changes in the near future are expected (TAgLiani et al. 2003). The increase in human activities directly related to the use of the estuarine waters suggest an uncertain future for the population of bottlenose dolphins and warns of the need to monitor this population on a long-term basis to allow the detection of possible changes in their dynamics as a consequence of such activities.

\section{ACKNOWLEDGMENTS}

We wish to thank Lauro Barcellos and the staff of the Museu Oceanográfico "Prof. Eliézer C. Rios" for the logistical support. The authors are grateful to Jonatas Prado, Paula Laporta, Munir Mehsen, Camila Pinto, Mônica Danielski, and 
Mauro Koga for assisting our research during field surveys. Thanks for your effort. Special thanks go to Altemir B. Pinto, who piloted our research vessel. This study was made possible by the financial support of Fundação O Boticário de Proteção à Natureza (Brazil), Cetacean Society International (United States of America), Yaqu Pacha Fundation (Germany) and The Whale and Dolphin Conservation Society (England). The Conselho Nacional de Desenvolvimento Científico e Tecnológico (Brazil) provided scholarships to E.R. Secchi (PQ 305219/2008-1), J.C. Di Tullio, and the Coordenação de Aperfeiçoamento de Pessoal de Nível Superior provided a scholarship to P.F. Fruet (Programa de Pós-Graduação em Oceanografia Biológica, Instituto de Oceanografia, Universidade Federal do Rio Grande). This is a contribution of the Research Group "Ecologia e Conservação da Megafauna Marinha - EcoMega/CNPq". This research is part of the Master's Dissertation written by the first author under the guidance of the last.

\section{LITERATURE CITED}

Azevedo, A.F.; A.M. Oliveira; L. Dalla Rosa \& J. Laison-Brito. 2007. Characteristics of whistles from resident bottlenose dolphins (Tursiops truncatus) in southern Brazil. Journal of Acoustic Society of America 121 (5): 2978-2983

BALLANCE, L.T. 1990. Residence patterns, group organization, and surfacing associations of bottlenose dolphins in Kino Bay, Gulf of California, Mexico, p. 267-283. In: S. Leatherwood \& R.R. Reeves (Eds). The Bottlenose Dolphin. New York, Academic Press.

BEGON, M. 1983. Abuses of mathematical techniques in ecology: applications of Jolly's capture-recapture method. Oikos 40 (1): 155-158.

Burnham, K.P.; D. R Anderson; G.C. White; C. Brownie \& K.H. PolLock. 1987. Design and analysis methods for fish survival experiments based on release-recapture. American Fisheries Society Monograph 5. Bethesda Maryland, American Fisheries Society, 737p.

Calambokidis, J.; J.C. Cubbage; G.H. Steiger; K.C. Balcomb \& P. Bloedel. 1990. Population estimates of humpback whales in the Gulf of the Farallones, California, p. 325-333. In: P.S. HAMMOND; S.A. Mizroch \& G.P. Donovan (Eds). Individual recognition of cetaceans: Use of photoidentification and other techniques to estimate population parameters. Cambridge, Reports of the International Whaling Commission, Special Issue 12.

Castello, H.P \& M.C. Pinedo. 1977. Botos na Lagoa dos Patos. Natureza em Revista 12: 46-49.

Chaо, A.; S.M. Lee \& S.L. Jeng. 1992. Estimating population size for capture-recapture data when capture probabilities vary by time and individual animal. Biometrics 48: 201-216.

Chapman, D.G. 1951. Some properties of the hypergeomtric distribution with applications to zoological censuses. University of California Publications in Statistical 1: 131160 .
Costa, C.S.B.; U. Seeliger; C.P.L. Oliveira \& A.M.M. Mazo. 1997. Distribuição, funções e valores das marismas e pradarias submersas no estuário da Lagoa dos Patos (RS, Brasil). Atlântica 19: 65-83.

Currey, R.J.C; S.M. Dawson \& E. SLooten. 2007. New abundance estimates suggest Doubtful Sound bottlenose dolphins are declining. Pacific Conservation Biology 13: 265-73.

Currey, R.J.C.; L.E. Rowe; S.M. Dawson \& E. Slooten. 2008. Abundance and demography of bottlenose dolphins in Dusky Sound, New Zealand, inferred from dorsal fin photographs. New Zealand Journal of Marine and Freshwater Research 42: 439-449.

Dalla Rosa, L. 1999. Estimativa do tamanho da população de botos, Tursiops truncatus, do estuário da Lagoa dos Patos, RS, a partir da foto-identificação de indivíduos com marcas naturais e da aplicação de modelos de marcação-recaptura. Rio Grande, Fundação Universidade Federal do Rio Grande, Master Thesis, 104p. Available on line at: http://www.botosdalagoa.com/arquivos/dissertacaoA.pdf [Accessed: 2.II.2011].

Fowler, C.W. \& J.D. BAKER. 1991. A review of animal population dynamics at extremely reduced population levels. Report of the International Whaling Commission 41: 545-554.

Friday, N.; T. Smith; P. Stevick \& J. Allen. 2000. Measurement of photographic quality and individual distinctiveness for the photographic identification of humpback whales, Megaptera novaeangliae. Marine Mammal Science 16: 355-374.

Fruet, P.F.; P.G. Kinas; K.G. DA Silva; J.C. DI Tullio; D.S. Monteiro; L. Dalla Rosa; S.C. Estima \& E.R. Secchi. 2010. Temporal trends in mortality and effects of bycatch on common bottlenose dolphins, Tursiops truncatus, in southern Brazil. Journal of the Marine Biological Association of the United Kingdom 91: 1-12. doi: 10.1017/S0025315410001888.

Hammond, P.S.; S.A. Mizroch \& G.F. Donovan. 1990. Individual recognition of cetaceans: Use of photo-identification and other techniques to estimate population parameters. Reports of the International Whaling Commission (Special Issue 12): 1-440.

Heppell, S.; C. Pfister \& H. De Kroon. 2000. Elasticity analysis in population biology: methods and applications. Ecology 81 (3): 605-606.

KJERFVE, B. 1986. Comparative oceanography of coastal lagoons, p. 63-81. In: D.A. Wolfe (Ed.). Estuarine variability. New York, Academic Press.

Leatherwood, S. \& R.R. Reeves. 1983. The Sierra Club Handbook of Whales and Dolphins. San Francisco, Sierra Club Books.

Mattos, P.H.; L. Dalla Rosa \& P.F. Fruet. 2007. Activity budgets and distribution of bottlenose dolphins (Tursiops truncatus) in the Patos Lagoon estuary, southern Brazil. Latin American Journal of Aquatic Mammals 6 (2): 161-169.

Möller, L.M.; J. Wiszniewski; S.J. Allen \& L.B. Beheregaray. 2007. Habitat type promotes rapid and extremely localized genetic differentiation in dolphins. Marine and Freshwater Research 58: 640-648. 
Mirlean, N.; Vlad E.A. \& P. Baisch. 2003. Mercury pollution sources in sediments of Patos Lagoon Estuary, Southern Brazil. Marine Pollution Bulletin 46 (3): 331-334.

Niencheski, L.F.H.; M.G. Z. Baumgarten; L. Cabrera \& S.K. Juliano. 2006. Patos Lagoon: indicators of organic pollution. Journal of Coastal Research (Special Issue) 39: 1356-1359.

Otis, D.L.; K.P. Burnham; G.C. White \& D.R. Anderson. 1978. Statistical inference from capture data on closed animal populations. Wildlife Monographs 62: 1-135.

Pinedo, M.C. 1986. Mortalidade de Pontoporia blainvillei, Tursiops gephyreus, Otaria flavescens e Arctocephalus australis na costa do Rio Grande do Sul, Brasil, 1976-1983, p. 187-199. In: Actas de la Primera Reunión de Trabajo de Expertos em Mamíferos Acuáticos de América del Sur. Buenos Aires.

Read, A.J.; P. Drinker \& S. Northridge. 2006. Bycatch of marine mammals in the U.S. and Global Fisheries. Conservation Biology 20: 163-169.

Reeves, R.R.; B.D. Smith; E.A. Crespo \& G.N. Di Sciara. 2003. Dolphins, Whales and Porpoises: 2002-2010 Conservation Plan for the World's Cetaceans. Cambridge, IUCN/SSC Cetacean Specialist Group 137p.

Reis, E.G. \& H. Rodrigues. 2003. Role of the forum of Patos Lagoon in the management of artisanal fisheries in the extreme south of Brazil. American Fisheries Society Symposium 38: 695-701.

Rexstad, E. \& K. Burnham. 1991. User's guide for interactive program Capture. Abundance estimation of closed animal populations. Colorado Cooperative Fish and Wildlife Research Unit. Fort Collins, Colorado State University, 29p.

SEBER, G.A.F. 1982. The estimation of animal abundance and related parameters. New York, MacMillan, $2^{\text {nd }}$ ed., 654p.

Simões-Lopes, P.C. \& M.E. Fabian. 1999. Residence patterns and site fidelity in bottlenose dolphins, Tursiops truncatus (Montagu) (Cetacea, Delphinidae) off Southern Brazil. Revista Brasileira de Zoologia 16 (4): 1017-1024.

SLooten, E. 2007. Conservation management in the face of uncertainty: effectiveness of four options for managing Hector's dolphin bycatch. Endangered Species Research 3: 169-179.

Submitted: 05.VIII.2010; Accepted: 26.XI.2010. Editorial responsibility: Cassiano Monteiro Neto
Tagliani, P.R.A.; H. Landazuri; E.G. Reis; C.R. Tagliani; M.L. Asmus \& A. SÁNChEZ-Arcilla. 2003. Integrated coastal zone management in the Patos Lagoon estuary: perspectives in context of developing country. Ocean \& Coastal Management 46: 807822.

Thompson, P.M.; B. Wilson; K. Grellier \& P.S. Hammond. 2000. Combining power analysis and population viability analysis to compare traditional and precautionary approaches to conservation of coastal cetaceans. Conservation Biology14: 1253-1263.

WADE, P.R. 1998. Calculating limits to the allowable human caused mortality of cetaceans and pinnipeds. Marine Mammal Science 14: 1-37.

WeLLS, R.S. 2000. Reproduction in wild bottlenose dolphins: overview of patterns observed during a long-term study, p. 57-74. In: D. DufField \& T. Rовеск (Eds). Bottlenose Dolphins Reproduction Workshop. Silver Springs, AZA marine mammal taxon advisory group.

WelLs, R.S. \& M.D. ScotT. 1990. Estimating bottlenose dolphin population parameters from individual identification and capture-release techniques. Report of the International Whaling Commission (Special issue 12): 407-415.

WelLs, R.S.; M.D. ScotT \& A.B. Irvine. 1987. The social strucutre of freeranging bottlenose dolphins, p. 247-305. In: H. Genoways (Ed.). Current Mammalogy. New York, Plenum Press, vol. 1.

Williams, J.A.; S.M. Dawson \& E. Slooten. 1993. The abundance and distribution of bottlenosed dolphins (Tursiops truncatus) in Doubtful Sound, New Zealand. Canadian Journal of Zoology 71: 2080-2088.

Wilson, B.; P.S. Hammond \& P.M. Thompson. 1999. Estimating size and assessing trends in a coastal bottlenose dolphin population. Ecological Applications 9: 288-300.

WURSIG, B. \& T.A. JefFerson. 1990. Methods of photo-identification for small cetaceans. Reports of the International Whaling Commission (Special Issue 12): 43-52.

WurSIG, B. \& M. WURSIG. 1977. The photographic determination of group size, composition, and stability of coastal porpoises (Tursiops truncatus). Science 198: 755-756. 